\title{
MATIG BOEK OVER RUGKLACHTEN
}

Jan Willem Elkhuizen, Menno Iprenburg. Rugpijn, hernia en spit. Hoe kom ik er vanaf? Uitgeverij Ipel, 2018. 143 pagina's.

ISBN 978-90-828-0730-1. Prijs € 20,-

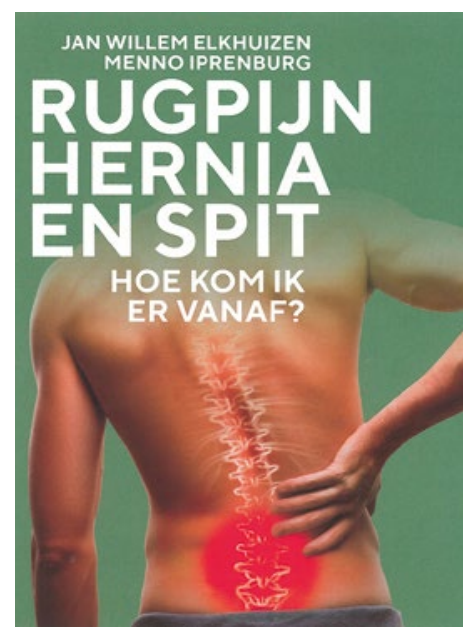

Dit boek beschrijft op toegankelijke wijze wat er gebeurt als iemand rugklachten heeft, hoe de patient daarmee moet omgaan en hoe hij (ergere) rugpijn kan voorkomen. Het bevat veel beeldmateriaal en praktische oefeningen. Daardoor is het boek bruikbaar bij voorlichting aan patiënten. De auteurs wijken echter wel enigszins af van de standaarden.

De auteurs zijn een orthopedisch chirurg/eigenaar van een herniakliniek en een bewegingswetenschaper/fysiotherapeut. Beiden hebben ruime ervaring met rugpatiënten. Met een 3D-model van de discus leggen ze uit welke krachten er in de annulus van de discus spelen. En passant introduceren ze een eigen, nog niet internationaal erkende theorie over weefselvocht dat in deze collagene vezels kan ontstaan door surmenage, net als bij andere collagene vezels in ons lichaam.

Het beleid in dit boek is niet helemaal in overeenstemming met de huidige NHG-Standaarden Lumbosacraal radiculair syndroom en Aspecifieke lagerugpijn. Zo noemen de auteurs de afspraken niet voor verwijzingen naar de neuroloog en krijgt MRI een grote plaats bij het stellen van een diagnose. Dat kan bij patiënten andere verwachtingen scheppen.

De ene auteur besteedt veel aandacht aan de verschillende operatietechnieken en dat levert een verhelderend hoofdstuk op. De andere auteur heeft veel oog voor preventie, met nuttige tips en oefeningen. U kunt dit boek gebruiken bij voorlichting aan patiënten, maar ik zou het niet snel aan patiënten aanbevelen.

Wilma Spinnewijn

WAARDERING: 